\title{
DnaK and GroEL are induced in response to antibiotic and heat shock in Acinetobacter baumannii
}

\author{
Karen Cardoso, ${ }^{1}$ Rinaldo Ferreira Gandra, ${ }^{2}$ Edirlene Sara Wisniewski, ${ }^{1}$ \\ Clarice Aoki Osaku, ${ }^{1}$ Marina Kimiko Kadowaki, ${ }^{1}$ Vicente Felipach-Neto, ${ }^{1}$ \\ Leandro Fávero Aby-Ázar Haus ${ }^{1}$ and Rita de Cássia Garcia Simão ${ }^{1}$ \\ ${ }^{1}$ Laboratório de Bioquímica Molecular, Centro de Ciências Médicas e Farmacêuticas, \\ Universidade Estadual do Oeste do Paraná, Cascavel, PR 85814-110, Brazil \\ ${ }^{2}$ Laboratório de Microbiologia Clínica, Hospital Universitário do Oeste do Paraná, Cascavel, \\ PR 85806-470, Brazil
}

Correspondence

Rita de Cássia Garcia Simão rcgsimao@unioeste.br or ritabioq@yahoo.com.br

Received 5 March 2010 Accepted 18 June 2010
We studied the expression of DnaK and GroEL in Acinetobacter baumannii cells (strains ATCC 19606 and RS4) under stress caused by heat shock or antibiotics. A Western blot assay showed that DnaK and GroEL levels increased transiently more than 2-fold after exposure of bacterial cells to heat shock for $20 \mathrm{~min}$ at $50{ }^{\circ} \mathrm{C}$. Heat induction of DnaK and GroEL was blocked completely when an inhibitor of transcription, rifampicin, was added 1 min before a temperature upshift to $50{ }^{\circ} \mathrm{C}$, suggesting that the induction of these chaperones depends on transcription. A. baumannii cells pretreated at $45{ }^{\circ} \mathrm{C}$ for $30 \mathrm{~min}$ were better able to survive at $50{ }^{\circ} \mathrm{C}$ for 60 min than cells pretreated at $37{ }^{\circ} \mathrm{C}$, indicating that $A$. baumannii is able to acquire thermotolerance. DnaK and GroEL were successfully induced in cells pre-incubated with a subinhibitory concentration of streptomycin. Moreover, bacterial cells pretreated for $30 \mathrm{~min}$ at $45{ }^{\circ} \mathrm{C}$ were better able to survive streptomycin exposure than cells pretreated at physiological temperatures. DnaK expression was upregulated in a multidrug-resistant strain of $A$. baumannii (RS4) in the presence of different antimicrobials (ampicillin + sulbactam, cefepime, meropenem and sulphamethoxazole + trimethoprim). This study is to the best of our knowledge the first to show that A. baumannii DnaK and GroEL could play an important role in the stress response induced by antibiotics.

\section{INTRODUCTION}

Acinetobacter baumannii is a non-fermentative, Gramnegative bacterium considered to be one of the most important opportunistic human pathogens. It can cause serious disease in compromised patients, including pneumonia, septicaemia, meningitis and urinary tract infections (Bergogne-Bérézin \& Towner, 1996). Various mechanisms of antibiotic resistance have been recognized in this species, and combination therapy is usually required for effective treatment of A. baumannii nosocomial infections (Falagas et al., 2006; Peleg et al., 2008).

Analysis of the total DNA sequence of A. baumannii ATCC 17978 revealed 16 putative alien islands predicted to be involved in virulence (Smith et al., 2007). In addition, a study by Fournier et al. (2006) typifies the genetic agility and broad resistance array of $A$. baumannii. The sequencing of the whole genome of a clinical epidemic $A$. baumannii strain in France (AYE) identified an $86 \mathrm{~kb}$ resistance island $(\mathrm{AbaR} 1)$. Of the 88 predicted ORFs within

Abbreviation: HSP, heat-shock protein. this genomic region, 82 were predicted to have originated from other bacteria, such as Escherichia coli and Pseudomonas and Salmonella species. Thus, the therapeutic challenges presented by $A$. baumannii infections are partially attributable to the fact that these bacteria exhibit significant genetic versatility in the acquisition of drug resistance and have the ability to survive in the hospital environment (Bergogne-Bérézin \& Towner, 1996; Peleg et al., 2008).

The heat-shock response is the mechanism by which cells react to increases in temperature to prevent damage, and it involves the expression of the almost universally conserved heat-shock genes. Many heat-shock proteins (HSPs) are molecular chaperones or proteases and function by facilitating refolding of damaged proteins or eliminating proteins that cannot be repaired (Gomes \& Simão, 2009). In bacteria, the major molecular chaperones include the DnaK machine (DnaK, DnaJ and GrpE) and the GroE machine (GroES and GroEL), while the ATP-dependent proteases include Lon, FtsH, ClpAP and ClpXP. GroEL acts by providing a protective microenvironment for protein 
folding, whereas DnaK acts by binding and protecting exposed regions on unfolded or partially folded protein chains from proteolysis and aggregation (Gomes \& Simão, 2009).

Infection of a mammal by a bacterial parasite is a complex process involving a series of recognition events and phenotypic alterations, during which cells of the host and the bacteria undergo a process of mutual recognition and adaptation (Lathigra et al., 1991). HSPs were assumed to play a role in infection, since microbial HSPs can stimulate immune responses in infected patients (Morrison et al., 1989; Misra et al., 1996; Mosier et al. 1998). However, temperature changes are not the only environmental trigger of HSP expression in bacteria: sublethal concentrations of ethanol, heavy metals, oxidative stress (Laport et al., 2006; Yura et al., 2000) and exposure to antibiotics (Neidhardt \& VanBogelen, 1987; Yamaguchi et al., 2003) can also induce HSP expression.

At the time of entrance in the new host, invading microorganisms like A. baumannii are subjected to a range of stressful conditions, such as elevated temperatures, increased ionic strength and host defences, which induce the bacterial stress response. Indeed, some of the HSPs are themselves virulence factors, while others affect pathogenesis indirectly by increasing bacterial resistance to host defences or regulating virulence genes (Gophna \& Ron, 2003).

Expression of the chaperones DnaK and GroEL was verified in Acinetobacter calcoaceticus using two-dimensional electrophoresis and $\mathrm{N}$-terminal amino acid sequencing. DnaK was found to be amplified in response to ethanol, butanol, hexanol and heat shock, but GroEL was amplified only in response to heat shock and ethanol treatment (Benndorf et al., 1999). The response to heat shock has greater similarity to the response to phenol treatment in A. calcoaceticus (Benndorf et al., 2001). The predominant induction of HSPs (ClpB, HtpG and DnaK) by phenol in this bacterium could be caused by its higher lipophilicity, which may determine the ability of a compound to induce HSPs (Benndorf et al., 1999, 2001). Despite these studies, the regulation of heat shock genes in members of the genus Acinetobacter remains poorly understood.

\section{METHODS}

Bacterial strains, culture conditions and susceptibility testing. A. baumannii strains ATCC 19606 and RS4 were incubated in LuriaBertani (LB) medium at $37{ }^{\circ} \mathrm{C}$ with constant aeration or on LB agar. A. baumannii RS4 was isolated by haemoculture in the clinical microbiology laboratory at West Paraná University Hospital (Cascavel, PR, Brazil) and identified by phenotypic markers according to Bouvet \& Grimont $(1986,1987)$. Species identification was confirmed by multiplex PCR (Chen et al., 2007). Susceptibilities to a variety of different antibiotics were determined by microbroth dilution in accordance with NCCLS performance and interpretive guidelines. Since A. baumannii RS4 is notoriously multidrug resistant
(Table 1), A. baumannii RS4 was grown at $37{ }^{\circ} \mathrm{C}$ in LB medium in both the presence and the absence of different antibiotics at a subinhibitory concentrations $\left(\mathrm{ml}^{-1}: 30 \mu \mathrm{g}\right.$ ampicillin plus $12 \mu \mathrm{g}$ sulbactam, $30 \mu \mathrm{g}$ cefepime, $18 \mu \mathrm{g}$ meropenem and $120 \mu \mathrm{g}$ sulphamethoxazole plus $8 \mu \mathrm{g}$ trimethoprim) to perform RT-PCR and Western blot assays. Overnight culture was used to inoculate $(1: 100$ dilution) $60 \mathrm{ml} \mathrm{LB}$ medium in a $250 \mathrm{ml}$ flask. Cultures were incubated with aeration at 180 r.p.m. at $37{ }^{\circ} \mathrm{C}$ to mid-exponential phase $\left(\mathrm{OD}_{600}\right.$ 0.7-0.8). Cells were then exposed to heat shock or antibiotics for different periods of time. Control cultures were grown for the same time in the absence of stress by temperature or antibiotics.

Western blot assays. A. baumannii ATCC 19606 was grown in LB medium to mid-exponential phase $\left(\mathrm{OD}_{600} 0.7-0.8\right)$ and exposed to different lengths of exposure ( 0 to $240 \mathrm{~min}$ ) to heat shock at 45 and $50{ }^{\circ} \mathrm{C}$ or to antibiotics $(10 \mu \mathrm{g}$ rifampicin or $200 \mu \mathrm{g}$ streptomycin $\mathrm{ml}^{-1}$ ). A. baumannii RS4 was grown in LB medium to midexponential phase $\left(\mathrm{OD}_{600} 0.7-0.8\right)$ and exposed to different lengths of exposure (0 to $60 \mathrm{~min}$ ) to antibiotics according to the protocol above. Cells were then collected and resuspended in Laemmli sample buffer. After SDS-PAGE (Laemmli, 1970), the proteins (equal amounts applied to each lane) were transferred to a nitrocellulose membrane, according to the method described by Towbin et al. (1979). The membranes were then treated as described by Avedissian \& Gomes (1996) using anti-DnaK and anti-GroEL sera generated against the Gram-negative bacterium Caulobacter crescentus (kindly donated by S. L. Gomes, Universidade de São Paulo).

Survival assays. To evaluate sensitivity to various types of stress (heat shock and antibiotic), A. baumannii ATCC 19606 was grown exponentially to mid-exponential phase in LB medium at $37^{\circ} \mathrm{C}$ and aliquots of culture were pretreated at $30 \mathrm{~min}$ with heat shock at $45^{\circ} \mathrm{C}$ and then exposed to extreme heat shock at $50{ }^{\circ} \mathrm{C}$ or to stress caused by a subinhibitory concentration of $200 \mu \mathrm{g}$ streptomycin $\mathrm{ml}^{-1}$. After treatment, cultures were diluted and plated on LB agar to determine the number of viable cells.

RNA extraction and RT-PCR analysis. An overnight culture of $A$. baumannii RS4 was diluted into fresh LB medium. When the culture reached exponential growth, $15 \mathrm{ml}$ culture was removed (as a negative control). Different antibiotic stocks were added separately $\left(\mathrm{ml}^{-1}: 30 \mu \mathrm{g}\right.$ ampicillin $+12 \mu \mathrm{g}$ sulbactam, $30 \mu \mathrm{g}$ cefepime, $18 \mu \mathrm{g}$ meropenem and $120 \mu \mathrm{g}$ sulphamethoxazole $+8 \mu \mathrm{g}$ trimethoprim) and incubation was continued for another $60 \mathrm{~min}$ at $37^{\circ} \mathrm{C}$. During the antibiotic incubation, further $15 \mathrm{ml}$ aliquots were removed at 20 , 40 and $60 \mathrm{~min}$. Immediately after the samples were collected, they were centrifuged at 12000 r.p.m. for $10 \mathrm{~min}$ and the supernatant was removed. Cell pellets were frozen and stored at $-40{ }^{\circ} \mathrm{C}$. RNA extraction was carried out as described by Hottes et al. (2004). Total

Table 1. Antimicrobial susceptibility of $A$. baumannii strains

MICs are given as $\mathrm{mg}^{-1}$. ND, Not determined/no data available. Data for strain ATCC 19606 were obtained from the ATCC.

\begin{tabular}{|lcc|}
\hline Antimicrobial(s) & ATCC $\mathbf{1 9 6 0 6}$ & RS4 \\
\hline Rifampicin & 2 & ND \\
Streptomycin & 256 & ND \\
Ampicillin + sulbactam & ND & $34 / 18$ \\
Cefepime & ND & 36 \\
Meropenem & ND & 22 \\
Sulphamethoxazole + trimethoprim & ND & $156 / 10$ \\
\hline
\end{tabular}


RNA extracted along with any contaminating DNA was digested with RNase-free DNase according to the manufacturer's instructions (Invitrogen) and the absence of residual DNA contamination was confirmed by PCR. RNA samples were further purified with acid $\mathrm{phenol/chloroform/isoamyl} \mathrm{alcohol}(25: 24: 1, \mathrm{pH} 4.5)$ (Invitrogen) extraction followed by salt/ethanol precipitation. RNA quantity was determined from the $A_{260}$, and quality was determined by $1.5 \%(\mathrm{w} / \mathrm{v})$ agarose gel electrophoresis and from the $A_{260} / A_{280}$ ratio. Aliquots of each RNA sample were used for RT-PCR analysis: specifically, $0.4 \mu \mathrm{g}$ total RNA prepared from cells incubated with ampicillin + sulbactam and cefepime and $1 \mu \mathrm{g}$ total RNA extracted from cells incubated with meropenem and sulphamethoxazole + trimethoprim. Transcript detection analysis was carried out by SuperScript OneStep RT-PCR with Platinum Taq kit (Invitrogen). A 933 bp fragment corresponding to the coding region of the A. baumannii dnaK gene was amplified using the forward primer dnaK-Met (5'-TATGAATTCAGCGCTAAGCGTCAGGCA- $3^{\prime}$ ) and the reverse primer dnaK-Half (5'-TATGGATCCTTTACGTGGCTCTCTACC-3'), which are complementary to the A. baumannii dnaK gene (GenBank accession number CP000521.1). RNase inhibitor (Invitrogen) was added to all RTPCRs. RT-PCR conditions were cDNA synthesis at $55{ }^{\circ} \mathrm{C}$ for $30 \mathrm{~min}$, after initial denaturation for $2 \mathrm{~min}$ at $94^{\circ} \mathrm{C}$, then cycling as follows: $15 \mathrm{~s}$ at $94{ }^{\circ} \mathrm{C}, 30 \mathrm{~s}$ at $55^{\circ} \mathrm{C}$ and elongation at $68{ }^{\circ} \mathrm{C}$ for $1 \mathrm{~min}$. After 40 cycles, a final extension at $68{ }^{\circ} \mathrm{C}$ for $5 \mathrm{~min}$ was carried out. Negative controls were carried out with Taq DNA polymerase (Invitrogen) in the absence of SuperScript reverse transcriptase to confirm that amplified products were not derived from DNA. RTPCR products were then resolved by electrophoresis on a $1 \%(\mathrm{w} / \mathrm{v})$ $1 \times$ TBE agarose gel.

\section{RESULTS AND DISCUSSION}

\section{Heat stress at $45{ }^{\circ} \mathrm{C}$}

To investigate the expression of chaperones by $A$. baumannii ATCC 19606 during heat shock, we incubated the strain at $45{ }^{\circ} \mathrm{C}$. A Western blot assay was performed which showed that the level of GroEL and DnaK expression did not change in untreated cells during the $60 \mathrm{~min}$ incubation (not shown). The levels of HSPs at zero time represent the control for this experiment (Fig. 1). DnaK and GroEL levels doubled after exposure to heat shock at $45{ }^{\circ} \mathrm{C}$ for $10 \mathrm{~min}$ (Fig. 1). However, constitutively expressed chaperones have been verified for almost $60 \mathrm{~min}$ at $45{ }^{\circ} \mathrm{C}$ in Acinetobacter. In fact, when this bacterium is incubated at $44{ }^{\circ} \mathrm{C}$, it can survive and grow normally over a 24-48 $\mathrm{h}$ period. This ability to tolerate moderate temperature $\left(44{ }^{\circ} \mathrm{C}\right)$ is commonly used to differentiate $A$. baumannii from other bacteria of the same genus in clinical microbiology laboratories (Bouvet \& Grimont, 1986, 1987). Similarly, at temperatures below $44^{\circ} \mathrm{C}$, the heat shock response in $E$. coli is superimposed on an essentially normal pattern of gene expression, suggesting that the synthesis of most proteins is not greatly affected by heat shock induction (Herendeen et al., 1979; Neidhardt \& VanBogelen, 1987).

\section{Heat shock response at extreme temperature}

In order to evaluate chaperone expression in A. baumannii ATCC 19606 at high temperatures, cells were grown to (a) Heat shock at $45^{\circ} \mathrm{C}$

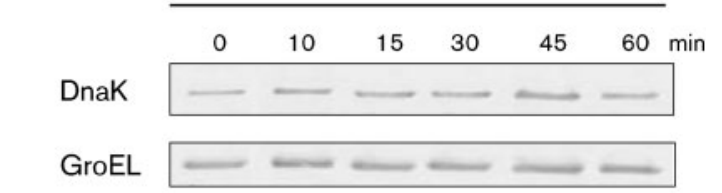

(b)

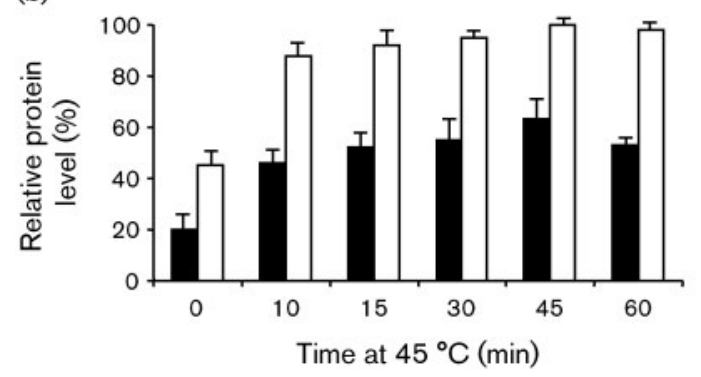

Fig. 1. Western blot analyses of DnaK and GroEL during heat shock at $45^{\circ} \mathrm{C}$. (a) A. baumannii ATCC 19606 was grown at midexponential phase and exposed to heat shock at $45^{\circ} \mathrm{C}$ for different times. Protein extracts were prepared and separated by SDS-PAGE. After transferring the proteins to nitrocellulose membranes, the blots were probed with anti-DnaK and antiGroEL antisera, as described in Methods. Equal amounts of protein were applied to all lanes. (b) Relative amounts of DnaK (filled bars) and GroEL (open bars) determined by densitometry scanning of the membrane shown in (a). The highest value obtained was for GroEL expression at $45 \mathrm{~min}$ (100\%); the other values are expressed relative to this value. The data presented are representative of three independent biological experiments and standard deviations are shown as vertical bars.

mid-exponential phase and incubated at $50{ }^{\circ} \mathrm{C}$ for $2 \mathrm{~h}$. A Western blot assay demonstrated that $A$. baumannii DnaK and GroEL were transiently expressed during heat shock at $50{ }^{\circ} \mathrm{C}$ (Fig. 2a, b). The heat shock response in bacteria is positively controlled at the transcriptional level by the product of the rpoH gene, the heat shock promoterspecific $\sigma^{32}$ subunit of RNA polymerase. In E. coli, the shutting off of the response occurs as a consequence of declining $\sigma^{32}$ levels and inhibition of $\sigma^{32}$ activity. The DnaK chaperone machine interferes with efficient binding of $\sigma^{32}$ to the RNA polymerase core, turning off the heat shock response (Blaszczak et al., 1995). Curiously, in C. crescentus, it was shown that downregulation of the response is independent of DnaK levels, whereas the chaperone ClpB is necessary for normal turning off of HSP synthesis (da Silva et al., 2003; Simão et al., 2005). At present, little is known about the regulation of genes that encode HSPs and their role during the heat shock response in A. baumannii.

In A. baumannii ATCC 19606, the levels of the chaperones DnaK and GroEL decreased during the first 20 min of heat shock at $50{ }^{\circ} \mathrm{C}$ when rifampicin, a transcription inhibitor, was added $1 \mathrm{~min}$ before the temperature increase to $50{ }^{\circ} \mathrm{C}$ (Fig. 2a, b). Similar to the observed heat shock response in 
(a)

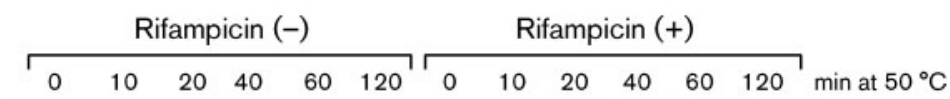

DnaK

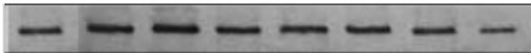

GroEL

\begin{tabular}{lllllllllllll}
\hline 0 & 10 & 20 & 40 & 60 & 120 & 0 & 10 & 20 & 40 & 60 & 120 & min at $50^{\circ} \mathrm{C}$
\end{tabular}

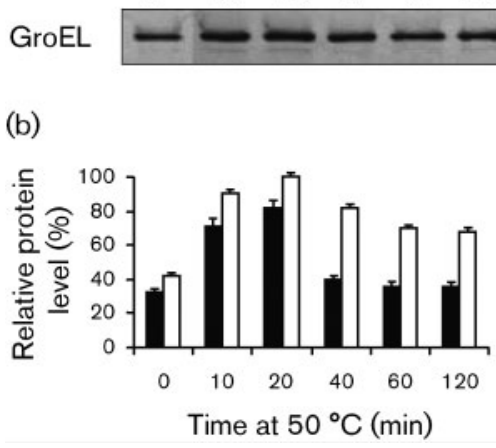

(b)

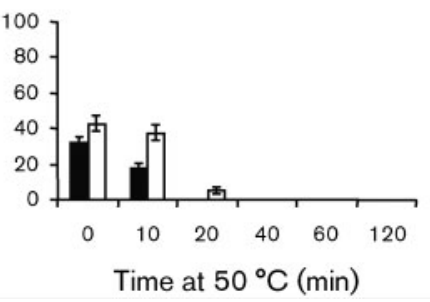

Fig. 2. Induction of DnaK and GroEL in $A$. baumannii depends on transcription. (a) $A$. baumannii ATCC 19606 was grown at $37{ }^{\circ} \mathrm{C}$ until mid-exponential phase with $(+)$ or without (-) $10 \mu \mathrm{g}$ rifampicin $\mathrm{ml}^{-1}$ and shifted to $50{ }^{\circ} \mathrm{C}$ for the indicated times. Aliquots of the culture were collected and proteins were analysed by SDS-PAGE followed by Western blot using antisera against $C$. crescentus DnaK and GroEL. Equal amounts of protein were applied to all lanes. (b) Relative amounts of DnaK (filled bars) and GroEL (open bars) determined by densitometry scanning of the membrane shown in (a). The largest value obtained was for GroEL expression at $20 \mathrm{~min}$ in the absence of rifampicin (100\%); the other values are expressed relative to this value. The data presented are representative of three independent biological experiments and standard deviations are shown as vertical bars.
E. coli, our results suggest that heat shock induction in $A$. baumannii depends on transcription.

\section{Thermotolerance}

The increased expression of HSPs in A. baumannii ATCC 19606 with preconditioning of cells at $45{ }^{\circ} \mathrm{C}$ constituted thermoprotection. Pre-incubation of A. baumannii cells for $30 \mathrm{~min}$ at $45{ }^{\circ} \mathrm{C}$ induced good thermoprotection to heat shock at $50{ }^{\circ} \mathrm{C}$; almost $80 \%$ of cells survived high temperature exposure for $15 \mathrm{~min}$ (Fig. 3). However, after this period at $50{ }^{\circ} \mathrm{C}$, only $48 \%$ of cells preconditioned at physiological temperatures survived. Control cells or cells

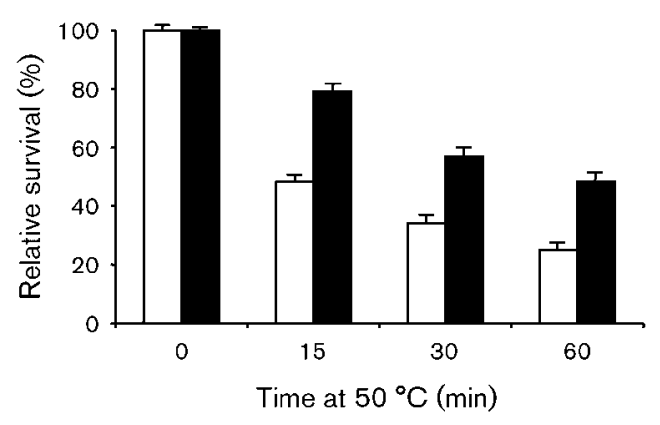

Fig. 3. $A$. baumannii is able to acquire thermotolerance. $A$. baumannii ATCC 19606 was grown exponentially to midexponential phase. Half of the cultures were preconditioned for $30 \mathrm{~min}$ at the non-lethal temperature of $45{ }^{\circ} \mathrm{C}$ (filled bars), while the other half were pre-incubated at $37{ }^{\circ} \mathrm{C}$ (open bars). Cultures were then exposed to $50{ }^{\circ} \mathrm{C}$ for $60 \mathrm{~min}$ and cell survival was evaluated after dilution and plating on LB agar. The graph represents means of three experiments, and the bars indicate standard deviations. not exposed to heat shock presented $100 \%$ survival during the 60 min period (not shown).

\section{Chaperone expression in response to antibiotics}

DnaK and GroEL levels were also analysed by Western blot assay in cells pre-incubated with streptomycin. The relative DnaK and GroEL protein levels at time zero were 13 and $59 \%$, respectively (Fig. 4a, b), and these levels were maintained during the period of $60 \mathrm{~min}$ for untreated control cells (not shown). DnaK increased more than 4fold after 60 min of exposure to a subinhibitory concentration of antibiotic, and GroEL levels doubled (Fig. 4a, b). Furthermore, A. baumannii cells pretreated for $30 \mathrm{~min}$ at $45{ }^{\circ} \mathrm{C}$ had an increased ability to survive antibiotic exposure compared with cells pretreated at physiological temperatures (Fig. 5). These results suggest that the chaperones DnaK and GroEL could play an important role in the stress response caused by streptomycin in $A$. baumannii.

\section{DnaK is upregulated in a multidrug-resistant strain of $A$. baumannii, RS4}

In order to analyse the role of HSP during the response to antibiotics in A. baumannii, DnaK expression was observed in the presence of subinhibitory concentrations of different antibiotics commonly used in the treatment of infectious diseases caused by this bacterium. Expression of dnaK was analysed at the transcriptional and translational levels using a multidrug-resistant strain of A. baumannii, RS4. The profile of $d n a K$ transcripts and protein expression was analysed by RT-PCR and Western blot, respectively. No changes were observed in the pattern of dnaK mRNA or DnaK protein expression for untreated RS4 cells during the $60 \mathrm{~min}$ period (not shown). Untreated control cells 
(a)

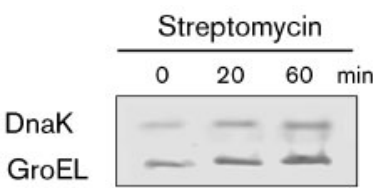

(b)

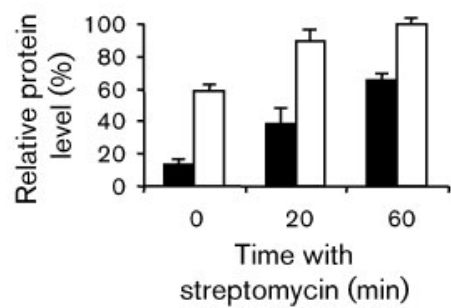

Fig. 4. HSPs are induced in the presence of streptomycin. (a) $A$. baumannii ATCC 19606 was grown at mid-exponential phase and incubated with $200 \mu \mathrm{g}$ streptomycin $\mathrm{ml}^{-1}$ for different times at $37{ }^{\circ} \mathrm{C}$. Protein extracts were prepared and separated by SDSPAGE. After transferring the proteins to nitrocellulose membranes, the blots were probed with anti-DnaK and anti-GroEL antisera, as described in Methods. Equal amounts of total protein were applied to all lanes. (b) Relative amounts of DnaK (filled bars) and GroEL (open bars) determined by densitometry scanning of the membrane shown in (a). The largest value obtained was for GroEL expression at $60 \mathrm{~min}$ in the presence of streptomycin (100\%); the other values are expressed relative to this value. The data presented are representative of three independent biological experiments and standard deviations are shown as vertical bars.

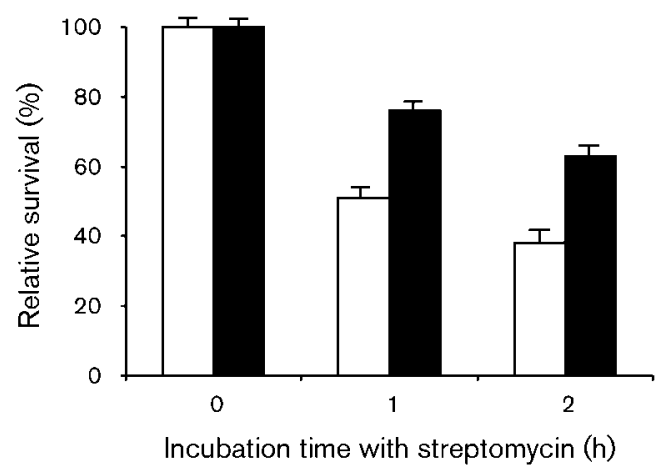

Fig. 5. Preconditioning of $A$. baumannii at $45^{\circ} \mathrm{C}$ makes cells more resistant to antibiotic effects. A. baumannii ATCC 19606 was grown to mid-exponential phase at $37{ }^{\circ} \mathrm{C}$ and pre-incubated at $45{ }^{\circ} \mathrm{C}$ (filled bars) or $37{ }^{\circ} \mathrm{C}$ (open bars) for $30 \mathrm{~min}$ and aliquots of the culture were exposed to $200 \mu \mathrm{g}$ streptomycin $\mathrm{ml}^{-1}$ for different lengths of time. Cultures were then diluted, plated on LB agar and incubated at $37{ }^{\circ} \mathrm{C}$ to determine the number of viable cells. Values represent percentages of cell survival (means of three independent experiments) with respect to control cultures performed in the absence of stress. Standard deviations are shown as vertical bars. displayed the same levels of transcripts and DnaK protein as visualized at time zero (Fig. 6) during the $60 \mathrm{~min}$ exposure. A susceptible strain was also tested under all of the study conditions. However, in contrast to the multidrug-resistant strain, cells of the susceptible strain died in the presence of the different antibiotics. Furthermore, short incubations of the susceptible strain with different drugs produced degraded RNA and proteolysis, preventing us from obtaining reliable results.

To analyse dnaK mRNA synthesis in the presence of different antibiotics, an RT-PCR assay was carried out as described in Methods using total RNA isolated from $A$. baumannii RS4 cells incubated with ampicillin + sulbactam for $60 \mathrm{~min}$ at $37^{\circ} \mathrm{C}$. dnaK mRNA synthesis increased gradually during the $60 \mathrm{~min}$ incubation with these antibiotics (Fig. 6a). dnaK transcription increased 1.5-fold after $20 \mathrm{~min}$ in the presence of ampicillin and more than 5fold after $60 \mathrm{~min}$ of exposure to the antibiotic. The amount of DnaK protein also increased in the presence of ampicillin + sulbactam: the levels at $40 \mathrm{~min}$ were twice those observed in the absence of the antibiotics $(0 \mathrm{~min})$. During ampicillin + sulbactam exposure for 20-60 min, A. baumannii exhibited variations in DnaK levels. These results indicate that the antibiotics ampicillin + sulbactam together induce expression of the dnaK gene in $A$. baumannii RS4 and suggest that the maintenance of DnaK levels depends on $d n a K$ gene transcription. In contrast, transcription of $d n a K$ increased drastically during cefepime exposure (about 5-fold), reaching maximum levels after $20 \mathrm{~min}$ of incubation with the antibiotic and decreasing to very low levels by $60 \mathrm{~min}$ (Fig. $6 \mathrm{~b}$ ).

Curiously, the exposure of RS4 cells to ampicillin or sulbactam alone did not induce dnaK mRNA synthesis as soon as DnaK protein (not shown). Sulbactam is a $\beta$ lactamase inhibitor that can bind to bacterial penicillinbinding proteins $\left(\mathrm{PBP}_{2}\right)$ that are involved in synthesizing and shaping the cell wall (Waxman \& Strominger, 1983). The combination of sulbactam with penicillin or cephalosporin may therefore have a synergic effect ( $\mathrm{Fu}$ et al., 2003; Choi et al., 2004).

In spite of the fact that A. baumannii exhibited transient transcription of the $d n a K$ gene in the presence of cefepime, the levels of DnaK protein more than doubled after $20 \mathrm{~min}$ exposure to the antibiotic and thereafter produced nearconstitutive levels of the protein up to $60 \mathrm{~min}$ (Fig. 6b). The amount of DnaK was actually maintained at the same level between $60 \mathrm{~min}$ and $2 \mathrm{~h}$ of exposure to cefepime (not shown). These results suggest that the initial levels of DnaK protein parallel the synthesis of dnaK mRNA; however, after $40 \mathrm{~min}$ of exposure to cefepime, a process that controls the translation of $d n a K$ mRNA transcripts or low DnaK proteolysis could favour high levels of this protein in A. baumannii.

A similar profile of expression was observed for the $d n a K$ gene at the transcriptional and translational levels in the presence of the antibiotics meropenem (Fig. 6c) and 
(a)

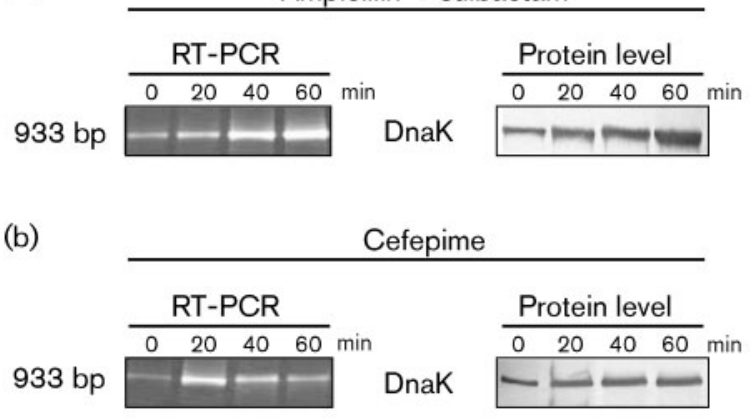

(c)

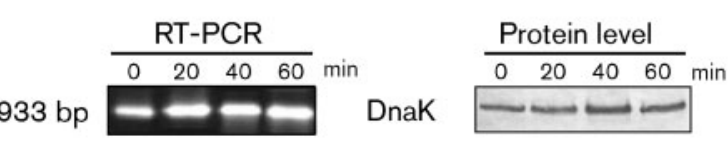

(d)

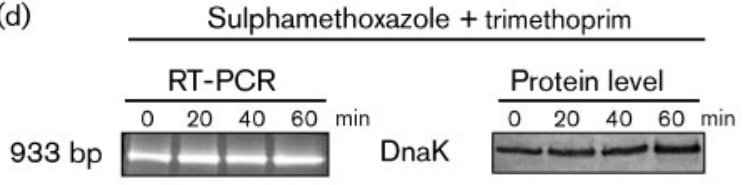

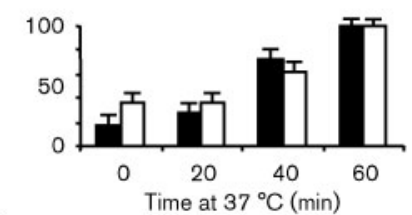
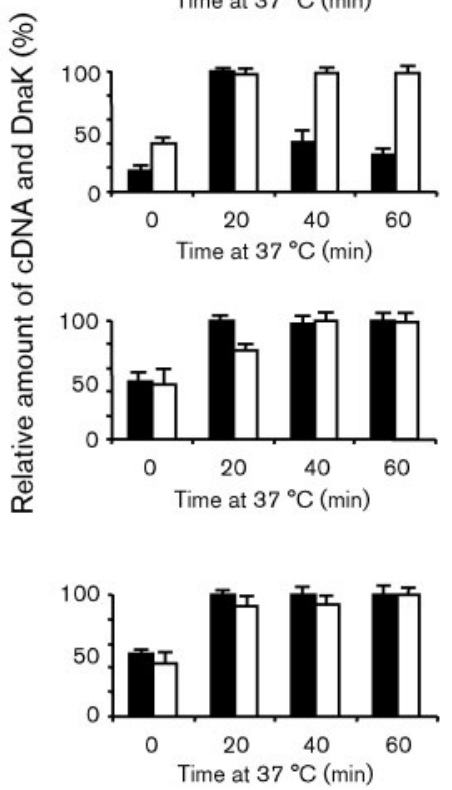

Fig. 6. Different antibiotics induce the expression of the dnaK gene in A. baumannii RS4. From left to right, the panels show levels of RNA and protein and densitometric views of these data. RT-PCR and Western blot assays were carried out as described in Methods using equal amounts of RNA and protein, respectively, extracted from A. baumannii RS4 cells cultured in the absence ( 0 min, negative control) and presence of different antibiotics after 20, 40 and 60 min at $37{ }^{\circ} \mathrm{C}$. As a negative control of the RT-PCR assay, all reactions were performed with Taq DNA polymerase in place of SuperScript reverse transcriptase and PCR products were visualized (not shown). Densitometry values were expressed relative to the highest levels of $d n a K$ cDNA or DnaK protein. The data presented are representative of three independent biological experiments. Standard deviations are shown as vertical bars.

sulphamethoxazole + trimethoprim (Fig. 6d). In both assays, the antibiotics induced almost twice the mRNA synthesis of the dnaK gene as DnaK protein in A. baumannii. As shown in Fig. 6(c,d), the relative rate of DnaK synthesis increased progressively during incubation, not only with meropenem, but also with sulphamethoxazole + trimethoprim. Thus, changes in the rate of DnaK synthesis during exposure to meropenem and sulphamethoxazole+ trimethoprim parallel the variations in the level of $d n a K$ mRNA. A. baumannii has a high degree of resistance to sulphamethoxazole + trimethoprim, and little is known about the genetic basis of resistance to these compounds in this bacterium (Van Looveren et al., 2004). Although mRNA dnaK presented a unique profile of expression in the presence of cefepime, the DnaK chaperone was highly induced by the three beta-lactam antibiotics after $60 \mathrm{~min}$ of incubation (Fig. 6a-c).

Although the amount of total RNA used in the RT-PCR assay was strictly identical for all incubation times with the same type of antibiotic, different amounts of RNA were used in independent experiments (see Methods). Consequently, variations in dnaK mRNA levels can be seen at time zero when the four treatments are compared (Fig. 6a-d). The experimental strategy conducted in the RT-PCR did not allow us to compare the exact amounts of dnaK mRNA obtained for the same incubation time with two or more antibiotics. However, the expression profiles obtained with all antimicrobial drugs were reproducible and clearly showed transcription induction of the dnaK gene.

Resistance to antibiotics typically occurs as a result of drug inactivation or modification, target alteration or reduced accumulation associated with decreased permeability and/ or increased efflux (Poole, 2002). The majority of these mechanisms of resistance depend on rapid overexpression of different kinds of protein (Peleg et al., 2008). A. baumannii RS4 is resistant to many antibiotics. Thus, it seems obvious that this bacterium is able to cope with cell damage caused by these drugs because it has the ability to express components of the antibiotic-resistance machinery. 
There is no evidence in the literature that HSPs could provide antibiotic resistance to bacteria, and this work does not intend to show that. However, our work showed that HSPs are upregulated at the transcriptional and translational levels by different kinds of antibiotic (Figs 4 and 6) and that this upregulation could improve the ability of the cell to cope with stress caused by antimicrobials (Fig. 5) and perhaps acts simultaneously with the antibioticresistance machinery to maintain cell survival.

Some studies have suggested a role for HSPs in the bacterial stress response cause by antibiotics. Yamaguchi et al. (2003) demonstrated that the chaperones DnaK and GroEL have an effect on the antimicrobial activity of the fluoroquinolone levofloxacin in E. coli. According to these authors, these chaperones might contribute to quinolone resistance because they sequester the aggregates that accumulate in cells exposed to fluoroquinolones. Furthermore, mutations in the dnaK, groEL and lon genes increased bacterial susceptibility to levofloxacin.

Recent studies have demonstrated that subinhibitory concentrations of the antimicrobials gentamicin and tobramycin induce a set of genes that affect the interaction of Pseudomonas aeruginosa with host cells, including the gene encoding Lon protease, which is known to play a role in protein quality control (Marr et al., 2007). In Staphylococcus aureus, a mutation in the dnaK gene increased the susceptibility of the meticillin-resistant strain COL to the antibiotics oxacillin and meticillin (Singh et al., 2007). In S. aureus, HSPs are thought to be involved in responses to antibiotics because they are induced when the cell wall is subjected to antibiotic stress (Singh et al., 2001; Utaida et al., 2003).

The rapid emergence of multidrug-resistant bacterial strains like A. baumannii RS4 calls for the development of novel antimicrobials. One possible alternative strategy in the development of these compounds is to identify molecular targets and design molecules with high specificity and affinity for these targets. DnaK has been used as a target in the development of a novel genre of biocides known as pyrrhocoricin-based peptides. Pyrrhocoricin binding prevents the frequent opening and closing of the multihelical lid over the peptide-binding pocket of DnaK, permanently closes the cavity and inhibits chaperoneassisted protein folding (Kragol et al., 2001). Pyrrhocoricin is able to kill tetracycline- and aminoglycoside-resistant strains of E. coli, Salmonella typhimurium, Klebsiella pneumoniae, Haemophilus influenzae and Moraxella catarrhalis at low-micromolar concentrations (Cudic et al., 2002).

Molecular chaperones clearly play important roles in bacterial stress tolerance, but their role in antibiotic tolerance is poorly understood in A. baumannii. In an effort to begin to elucidate these roles, the present study verified the expression of $d n a K$ and groEL genes at the transcriptional and translational levels in the presence of antibiotics, and our results demonstrate that GroEL and
DnaK may have an important role during the stress response caused by antibiotics in A. baumannii. Further studies are under way in our laboratory to characterize the function of these chaperones in the antibiotic response.

\section{ACKNOWLEDGEMENTS}

We are grateful to Suely L. Gomes (Universidade de São Paulo, Brazil) for providing anti-DnaK and anti-GroEL sera. K.C., E.S.W. and V.F.-N. are fellows of CNPq. This work was supported by a grant from the Fundação Araucária, Fundo Paraná/SETI and CNPq.

\section{REFERENCES}

Avedissian, M. \& Gomes, S. L. (1996). Expression of the groESL operon is cell cycle controlled in Caulobacter crescentus. Mol Microbiol 19, 79-89.

Benndorf, D., Loffhagen, N. \& Babel, W. (1999). Induction of heat shock proteins in response to primary alcohols in Acinetobacter calcoaceticus. Electrophoresis 20, 781-789.

Benndorf, D., Loffhagen, N. \& Babel, W. (2001). Protein synthesis patterns in Acinetobacter calcoaceticus induced by phenol and catechol show specificities of responses to chemostress. FEMS Microbiol Lett 200, 247-252.

Bergogne-Bérézin, E. \& Towner, K. J. (1996). Acinetobacter spp. as nosocomial pathogens: microbiological, clinical, and epidemiological features. Clin Microbiol Rev 9, 148-165.

Blaszczak, A., Zylicz, M., Georgopoulos, C. \& Liberek, K. (1995). Both ambient temperature and the DnaK chaperone machine modulate the heat shock response in Escherichia coli by regulating the switch between $\sigma^{70}$ and $\sigma^{32}$ factors assembled with RNA polymerase. $E M B O J \mathbf{1 4}, 5085-5093$

Bouvet, P. J. M. \& Grimont, P. A. D. (1986). Taxonomy of the genus Acinetobacter with the recognition of Acinetobacter baumannii sp. nov., Acinetobacter haemolyticus sp. nov., Acinetobacter johnsonii sp. nov., and Acinetobacter junii sp. nov. and emended descriptions of Acinetobacter calcoaceticus and Acinetobacter lwoffii. Int J Syst Bacteriol 36, 228-240.

Bouvet, P. J. \& Grimont, P. A. (1987). Identification and biotyping of clinical isolates of Acinetobacter. Ann Inst Pasteur Microbiol 138, 569578.

Chen, T. L., Siu, L. K., Wu, R. C., Shaio, M. F., Huang, L. Y., Fung, C. P., Lee, C. M. \& Cho, W. L. (2007). Comparison of one-tube multiplex PCR, automated ribotyping and intergenic spacer (ITS) sequencing for rapid identification of Acinetobacter baumannii. Clin Microbiol Infect 13, 801-806.

Choi, J. Y., Park, Y. S., Cho, C. H., Park, Y. S., Shin, S. Y., Song, Y. G., Yong, D., Lee, K. \& Kim, J. M. (2004). Synergic in vitro-activity of imipenem and sulbactam against Acinetobacter baumannii. Clin Microbiol Infect 10, 1098-1101.

Cudic, M., Condie, B. A., Weiner, D. J., Lysenko, E. S., Xiang, Z. O., Insug, O., Bulet, P. \& Otvos, L., Jr (2002). Development of novel antibacterial peptides that kill resistant isolates. Peptides 23, 20712083.

da Silva, A. C. A., Simão, R. C. G., Susin, M. F., Baldini, R. L., Avedissian, M. \& Gomes, S. L. (2003). Downregulation of the heat shock response is independent of DnaK and $\sigma^{32}$ levels in Caulobacter crescentus. Mol Microbiol 49, 541-553.

Falagas, M. E., Koletsi, P. K. \& Bliziotis, I. A. (2006). The diversity of definitions of multidrug-resistant (MDR) and pandrug-resistant 
(PDR) Acinetobacter baumannii and Pseudomonas aeruginosa. J Med Microbiol 55, 1619-1629.

Fournier, P.-E., Vallenet, D., Barbe, V., Audic, S., Ogata, H., Poirel, L., Richet, H., Robert, C., Mangenot, S. \& other authors (2006). Comparative genomics of multidrug resistance in Acinetobacter baumannii. PLoS Genet 2, e7.

Fu, W., Demei, Z., Shi, W., Fupin, H. \& Yingyuan, Z. (2003). The susceptibility of non-fermentative Gram negative bacilli to cefoperazone and sulbactam compared with other antibacterial agents. Int $\mathrm{J}$ Antimicrob Agents 22, 444-448.

Gomes, S. L. \& Simão, R. C. G. (2009). Stress response: heat. In Encyclopedia of Microbiology, pp. 464-474. Edited by M. Schaechter. Oxford: Elsevier Academic Press.

Gophna, U. \& Ron, E. Z. (2003). Virulence and heat shock response. Int J Med Microbiol 292, 453-461.

Herendeen, S. L., VanBogelen, R. A. \& Neidhardt, F. C. (1979). Levels of major proteins of Escherichia coli during growth at different temperatures. J Bacteriol 139, 185-194.

Hottes, A. K., Meewan, M., Yang, D., Arana, N., Romero, P., McAdams, H. H. \& Stephens, C. (2004). Transcriptional profiling of Caulobacter crescentus during growth on complex and minimal media. J Bacteriol 186, 1448-1461.

Kragol, G., Lovas, S., Varadi, G., Condie, B. A., Hoffmann, R. \& Otvos, L., Jr (2001). The antibacterial peptide pyrrhocoricin inhibits the ATPase actions of DnaK and prevents chaperone-assisted protein folding. Biochemistry 40, 3016-3026.

Laemmli, U. K. (1970). Cleavage of structural proteins during the assembly of the head of bacteriophage T4. Nature 227, 680-685.

Laport, M. S., dos Santos, L. L., Lemos, J. A. C., Bastos, M. C. F., Burne, R. A. \& Giambiagi-deMarval, M. (2006). Organization of heat shock dnaK and groE operons of the nosocomial pathogen Enterococcus faecium. Res Microbiol 157, 162-168.

Lathigra, R. B., Butcher, P. D., Garbe, T. R. \& Young, D. B. (1991). Heat shock proteins as virulence factors of pathogens. Curr Top Microbiol Immunol 167, 125-143.

Marr, A. K., Overhage, J., Bains, M. \& Hancock, R. E. W. (2007). The Lon protease of Pseudomonas aeruginosa is induced by aminoglycosides and is involved in biofilm formation and motility. Microbiology 153, 474-482.

Misra, N., Habib, S., Ranjan, A., Hasnain, S. E. \& Nath, I. (1996). Expression and functional characterization of the $c l p C$ gene of Mycobacterium leprae: ClpC protein elicits human antibody response. Gene 172, 99-104.

Morrison, R. P., Belland, R. J., Lyng, K. \& Caldwell, H. D. (1989). Chlamydial disease pathogenesis: the $57-\mathrm{kD}$ chlamydial hypersensitivity antigen is a stress response protein. J Exp Med 170, 12711283.
Mosier, D., landolo, J., Rogers, D., Uhlich, G. \& Crupper, S. (1998). Characterization of a $54-\mathrm{kDa}$ heat-shock-inducible protein of Pasteurella haemolytica. Vet Microbiol 60, 67-73.

Neidhardt, F. C. \& VanBogelen, R. A. (1987). Heat shock response. In Escherichia coli and Salmonella typhimurium: Cellular and Molecular Biology, pp. 1334-1345. Edited by F. C. Neidhardt, J. L. Ingraham, K. B. Low, B. Magasanik, M. Schaechter \& H. E. Umbarger. Washington, DC: American Society for Microbiology.

Peleg, A. Y., Seifert, H. \& Paterson, D. L. (2008). Acinetobacter baumannii: emergence of a successful pathogen. Clin Microbiol Rev 21, 538-582.

Poole, K. (2002). Mechanisms of bacterial biocide and antibiotic resistance. J Appl Microbiol 92, 55S-64S.

Simão, R. C. G., Susin, M. F., Martinez, C. E. A. \& Gomes, S. L. (2005). Cells lacking ClpB display a prolonged shutoff phase of the heat shock response in Caulobacter crescentus. Mol Microbiol 57, 592-603.

Singh, V. K., Jayaswal, R. K. \& Wilkinson, B. J. (2001). Cell wall-active antibiotic induced proteins of Staphylococcus aureus identified using a proteomic approach. FEMS Microbiol Lett 199, 79-84.

Singh, V. K., Utaida, S., Jackson, L. S., Jayaswal, R. K., Wilkinson, B. J. \& Neal, R. (2007). Role for dnaK locus in tolerance of multiple stresses in Staphylococcus aureus. Microbiology 153, 3162-3173.

Smith, M. G., Gianoulis, T. A., Pukatzki, S., Mekalanos, J. J., Ornston, L. N., Gerstein, M. \& Snyder, M. (2007). New insights into Acinetobacter baumannii pathogenesis revealed by high-density pyrosequencing and transposon mutagenesis. Genes Dev 21, 601-614.

Towbin, H., Staehelin, T. \& Gordon, J. (1979). Electrophoretic transfer of proteins from polyacrylamide gels to nitrocellulose sheets: procedure and some applications. Proc Natl Acad Sci U S A 76, 4350-4354.

Utaida, S., Dunman, P. M., Macapagal, D., Murphy, E., Projan, S. J., Singh, V. K., Jayaswal, R. K. \& Wilkinson, B. J. (2003). Genome-wide transcriptional profiling of the response of Staphylococcus aureus to cell-wall-active antibiotics reveals a cell-wall-stress stimulon. Microbiology 149, 2719-2732.

Van Looveren, M., Goossens, H. \& the ARPAC Steering Group (2004). Antimicrobial resistance of Acinetobacter spp. in Europe. Clin Microbiol Infect 10, 684-704.

Waxman, D. J. \& Strominger, J. L. (1983). Penicillin-binding proteins and the mechanism of action of beta-lactam antibiotics. Annu Rev Biochem 52, 825-869.

Yamaguchi, Y., Tomoyasu, T., Takaya, A., Morioka, M. \& Yamamoto, T. (2003). Effects of disruption of heat shock genes on susceptibility of Escherichia coli to fluoroquinolones. BMC Microbiol 3, 16-23.

Yura, T., Kanemori, M. \& Morita, M. T. (2000). Heat shock response: regulation and function. In Bacterial Stress Response, pp. 3-18. Edited by G. Storz \& R. Hengge-Aronis. Washington, DC: American Society for Microbiology. 